\title{
Business Innovation: Implementation Digital Transformation and Digital Leadership in Era Industrial Revolution 4.0
}

\author{
Amaliyah \\ Economics and Business Department \\ University of Trilogi \\ Jakarta, Indonesia \\ amaliyah@trilogi.ac.id
}

\begin{abstract}
Some time later, the world economy experienced changes. The economic growth of the United States is estimated to remain strong. During the monetary crisis in 1998, the current state of the global economy had no effect on Cooperatives and SMEs. The reason is because at that time almost no SMEs borrowed money from foreign parties. However, this does not apply today. The contact of SMEs with foreign exchange is the cause. Besides that, SMEs in Indonesia also have problems with financial access and access to markets, namely the difficulty of adapting to technological advancements. Technological advances have touched on the development of digital with artificial intelligence components that can only be done if SMEs do Digital Transformation. SMEs must pay attention to their determinants of success, namely technological excellence, IT Capability, and IT Alignments with Business. These factors will be more quickly controlled and fulfilled if SME leaders have good vision and a strong understanding of Digital transformation. This research used causal study with a quantitative approach. Causal research is research that analyzes causal relationships between variables that are independent variables and dependent variables. If the SME leadership is able to support the Digital transformation process that is carried out, then SMEs will be able to carry out business innovations that can grow rapidly. This will make SMEs have the ability to compete and certainly contribute to the nations economy.
\end{abstract}

Keywords- Technological Excellence, Digital Leadership, Business Innovation

\section{INTRODUCTION}

The world economy has changed dramatically. The economic growth of the United States is still stable. On the other hand, economic growth in emerging market and European countries is not stable. During the monetary crisis in 1998, the current state of the global economy had no effect on Cooperatives and SMEs. The reason is because at that time almost no SMEs borrowed money from foreign parties. With the enactment of normalization of American monetary policy that has an impact on the strengthening of the US dollar, the global economic turmoil that occurred has made SMEs in Indonesia experience the impact. The contact of SMEs with foreign exchange is the cause (Anonymous, 2018).
Even though SMEs will be affected, it is nothing to worry about. According to Ryan, Indonesian entrepreneurs have experience in navigating the flow of economic dynamics, so that the impact that will be felt is not too large. The good purchasing power of the people also plays a role in maintaining the stability of the Indonesian economy, especially in the case of SMEs. This can be seen from the level of household consumption in the third quarter of 2018 which reached around 5.01 percent. Meanwhile, previously it was higher, which touched 5.14 percent in the second quarter (Anonymous, 2018).

However, this condition can change dramatically in 2019. Given that, in 2019 the world has entered the Industrial Revolution 4.0 era, which is not necessarily all SMEs are ready to deal with. In the process, many large companies are currently having difficulties implementing. Therefore, efforts to introduce, as well as increase the level of small and medium enterprises to adapt in the industrial era 4.0 still have severe challenges (Roeslani, 2018).

Small and medium-sized businesses in the country which currently involve approximately 59 million people. With that great potential, its development efforts must be a top priority for the government and its businessmen. Therefore, technological changes that are so fast not only bring positive aspects, but can also be the opposite. So, a special strategy is needed that is able to bridge the transition process (Roeslani, 2018).

Because currently SMEs in Indonesia also have problems with financial access and access to markets, the biggest obstacle faced is the difficulty of adapting to technological progress. Current technological progress is not just about device updates, but also has touched on digital development with artificial intelligence components that can only be done if SMEs carry out Digital Transformation. Digital transformation itself has meaning as a profound and comprehensive change in the company to maximize the use of digital technology to improve the efficiency and effectiveness of all activities that contribute to the achievement of company goals (Ganguly, 2015; Kwon \& Park, 2017). 
However, it is certainly not easy for an UKM to do Digital Transformation, because SMEs must really pay attention to the factors that determine their success, including technological excellence, IT Capability, and IT Alignment with Business. These factors will be more quickly controlled and fulfilled if SME leaders have good vision and a strong understanding of Digital transformation, but if the opposite is the case, the SME leadership will actually be a thing that weakens the process of going towards Digital transformation itself (Kwon \& Park, 2017; Nwankpa \& Roumani, 2016; Rastislav \& Silvia, 2015; Sow \& Aborbie, 2018).

If the leadership carried out by SMEs is able to support the Digital transformation process that is carried out, then SMEs will be able to carry out business innovations that can develop rapidly. This will make SMEs have the ability to compete and certainly contribute to the nation's economy (Rastislav \& Silvia, 2015). Companies that are able to carry out innovations, whether in the form of development or creation, tend to be companies that are able to survive through continuous improvement in performance (Nwankpa \& Roumani, 2016).

Digital transformation can be measured based on the use of digital technology in business to provide digital experience to customers, digitizing operational processes, and the ability to drive digital business models. CEO Digital Leadership can be measured based on the accuracy of decisions taken by the CEO in the digital transformation process, for example in the form of vision, regulation, empowerment of human resources, and technology investment decisions (Kwon \& Park, 2017).

IT expertise refers to the ability, experience, and knowledge related to the field of digital technology that can contribute greatly to effective decision making for the development of corporate informatization. IT Capability is the company's ability to formulate and implement IT-based resources combined with other company resources.

Conformity between IT and business in practice is not only useful for anticipating this, but in depth is able to encourage increased competitiveness of companies through value creation in the form of reducing costs and increasing business profits that the company can obtain.

The 4.0 industrial revolution itself is currently starting to take place. This is evident in the emergence of trends that combine automation technology with cyber technology which includes the scope of cyber-physical, Internet of Things (IoT), Cloud Computation and Cognitive Computation.

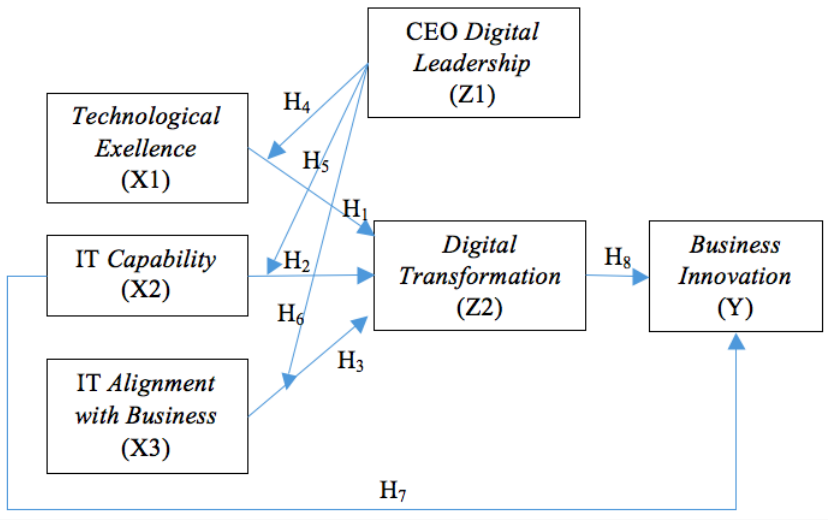

Fig. 1. Conceptual Framework

Research Hypothesis

H1: Technological Excellence has a significant effect on Digital Transformation

H2: IT Capability has a significant effect on Digital Transformation

H3: IT Alignment with Business has a significant effect on Digital Transformation

H4: CEO of Digital Leadership moderates the influence of Technological Excellence on digital transformation

H5: CEO of Digital Leadership moderates the influence of IT Capability on digital transformation

H6: CEO of Digital Leadership moderates the influence of IT Alignment with Business on digital transformation

H7: IT Capability has a significant effect on Business Innovation

H8: Digital Transformation has a significant effect on Business Innovation

\section{METHODS}

\section{A. Types of research}

This research is a causal study with a quantitative approach. Causal research is research that analyzes the causal relationship between variables that are influential (independent variables) and variables that are affected (dependent variable). The approach used is quantitative, which is an approach that uses static methods to analyze research data in the form of numbers. The results of the analysis are presented in the form of a description of the data and the results of the static tests used to answer the hypotheses developed in the study (Sugiyono, 2012).

\section{B. Population}

The population used in this study consisted of all SMEs in Surabaya. Based on an unknown population, the determination of the number of research samples is based on the calculation of the sample for unknown population as follows:

$$
n=\frac{Z^{2}}{4 M^{2}}
$$

$\mathrm{n}=96.4=96$ respondents 
Thus, the total sample of this study was 96 SME owners in Surabaya. Each of these SMEs will be represented by the owner in answering questions posed by researchers in the research data collection instrument.

\section{Data Analysis}

The research data that has been collected using a questionnaire will then be analyzed using the static method with the help of SPSS and SEM PLS programs. The SPSS program will be used for descriptive data analysis while PLS SEM will be used to test the research model and hypothesis (Ghozali, 2014).

\section{Data Collection Instrument}

The research data was collected using an instrument in the form of a questionnaire that will be distributed to respondents via e-mail. The statement in the research questionnaire was arranged based on operational variables as follows:

\section{RESULTS AND DISCUSSION}

The significance test on the SEM model with PLS aims to determine the effect of exogenous variables on endogenous variables. Hypothesis testing with SEM PLS method is done by doing the bootstrapping process with the help of a smartPLS 2.0 computer program in order to obtain the relationship of the influence of exogenous variables on endogenous variables. Based on the table II, it can be seen that the test results show results above the required critical value of 1.96, there are only two hypotheses that show critical values that are below the critical value required. The results are as follows:

1. Technological Excellence has proven to have a significant influence on digital transformation. Technological excellence is the achievement of new technology and the success of its use in creating business innovation, increasing IT expertise, and developing IT strategic roles in MSMEs, so that the better utilization of technology in these MSMEs, the greater the success of digital transformation in MSMEs (Kwon \& Park , 2017).

TABLE I. OPERATIONAL VARIABLE

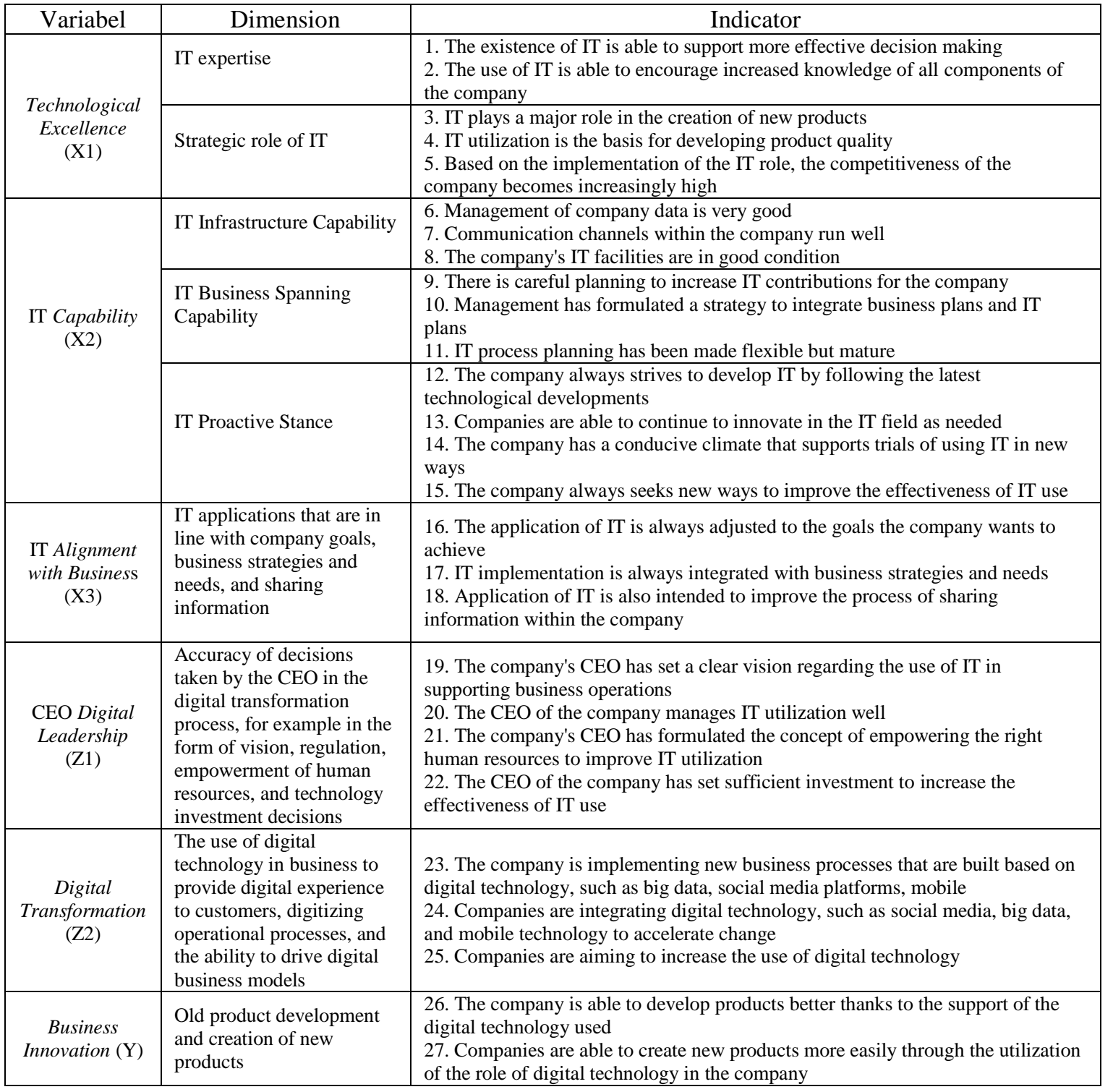


2. IT Capability has proven to have a significant influence on digital transformation. IT Capability is the company's ability to formulate and implement IT-based resources combined with other company resources. IT Capability does not only refer to aspects of technological capabilities, but also relates to all aspects or components within the company, which together form IT resources, along with related capabilities and knowledge that are the basis for the company to coordinate and achieve expected results (Nwankpa \& Roumani, 2016). That is, if the existence of IT on MSMEs has good capabilities, then changes in MSMEs that lead to the use of digital technology to improve the efficiency and effectiveness of all activities that contribute to the achievement of company goals will be achieved.

3. The existence of IT in a company becomes one of the main resources that are expected to play a major role in efforts to achieve the company's business goals. Therefore, there must be conformity between the aspects of IT and the business of the company, that the strategy, goals and needs of the business must be synergized with IT in order to be able to implement IT at the right time and always in accordance with the main priorities of management (Kwon \& Park, 2017). That is, if the business needs of MSMEs can synergize well with the existence of IT that is utilized, it will increasingly be able to support changes in MSMEs to be more effective and efficient because they have adopted digital technology.

TABLE II. BOOTSTRAPING DATA

\begin{tabular}{|c|c|c|c|}
\hline Hypothesis & Effect & t-Result & Results \\
\hline H1 & $\begin{array}{l}\text { Technological Excellence } \\
\text { has a significant effect on } \\
\text { Digital Transformation }\end{array}$ & 2,694060 & Proven \\
\hline $\mathrm{H} 2$ & $\begin{array}{l}\text { IT Capability has a } \\
\text { significant effect on } \\
\text { Digital Transformation }\end{array}$ & 3,218237 & Proven \\
\hline H3 & $\begin{array}{lr}\text { IT } & \text { Alignment with } \\
\text { Business has a significant } \\
\text { effect on Digital } \\
\text { Transformation }\end{array}$ & 2,046217 & Proven \\
\hline $\mathrm{H} 4$ & $\begin{array}{l}\text { CEO of Digital } \\
\text { Leadership moderates the } \\
\text { influence of } \\
\text { Technological Excellence } \\
\text { on digital transformation }\end{array}$ & 2,601296 & Proven \\
\hline H5 & $\begin{array}{l}\text { The CEO of Digital } \\
\text { Leadership moderates the } \\
\text { influence of IT Capability } \\
\text { on digital transformation }\end{array}$ & 0,935092 & $\begin{array}{l}\text { Not } \\
\text { Proven }\end{array}$ \\
\hline H6 & $\begin{array}{l}\text { CEO of Digital } \\
\text { Leadership moderates the } \\
\text { influence of IT Alignment } \\
\text { with Business on digital } \\
\text { transformation }\end{array}$ & 0,469569 & $\begin{array}{l}\text { Not } \\
\text { Proven }\end{array}$ \\
\hline H7 & $\begin{array}{l}\text { IT Capability has a } \\
\text { significant effect on } \\
\text { Business Innovation }\end{array}$ & 2,215806 & Proven \\
\hline H8 & $\begin{array}{l}\text { Digital Transformation } \\
\text { has a significant effect on } \\
\text { Business Innovation }\end{array}$ & 2,464335 & Proven \\
\hline
\end{tabular}

4. The CEO of Digital Leadership is proven to be able to significantly moderate the influence of technological excellence on digital transformation. This shows that with a MSME having a leader who is able to initiate a company change that leads to a digital basis, the company will be more mature in preparing and planning the use of technology in its company quite mature, and in the end will be able to do digital transformation perfectly (Kwon \& Park, 2017).

5. The CEO of Digital Leadership is not proven to significantly moderate the influence of IT Capability on digital transformation. This reflects that even though a leader has a vision and is able to initiate a change in the company towards a digital base with the support of cutting-edge technology, if the capacity of IT resources is not sufficient, digital transformation will not run smoothly (Nwankpa \& Roumani, 2016).

6. The CEO of Digital Leadership is not proven to significantly moderate the influence of IT Alignment with Business on digital transformation. This represents the leader in the company has not been fully able to run the operation of the company in accordance with the expected business objectives. This causes an imbalance between IT and business strategy that causes digital transformation to be carried out that cannot run optimally. In the event of such conditions, the company may experience a large loss because the IT development

7. that is owned turns out to be unable to be implemented maximally and is unable to provide the expected contribution in achieving business goals (Kwon \& Park, 2017).

8. IT Capability has proven to have a significant influence on Business Innovation. This shows that with the presence of good IT capabilities in the company, the company will increasingly be able to maneuver in realizing its business innovation. Companies that are able to carry out innovations, whether in the form of development or creation, tend to be companies that are able to survive through continuous improvement in performance (Nwankpa \& Roumani, 2016).

9. Digital Transformation has proven to have a significant influence on Business Innovation. This shows that when a company is able to do digital transformation well, then the company indirectly has made an innovative effort. With the higher level of innovation of a company, the MSMEs will become companies that are able to compete and improve their business performance (Nwankpa \& Roumani, 2016)

\section{CONCLUSION}

Based on the results of the tests and discussions that have been presented in advance, it can be concluded that:

1. The first hypothesis which states that technological excellence has a significant effect on digital transformation can be proven to be true.

2. The second hypothesis which states that IT alignment with business has a significant effect on digital transformation can be proven true. 
3. The third hypothesis which states that IT alignment with business has a significant effect on digital transformation can be proven true.

4. The fourth hypothesis which states that the CEO of digital leadership moderates the influence of technological excellence on digital transformation can be proven to be true.

5. The fifth hypothesis which states that the CEO of digital leadership moderates the influence of an IT capability on digital transformation cannot be proven to be true.

6. The sixth hypothesis which states that the CEO of digital leadership moderates the influence of IT alignment with business on digital transformation cannot be proven to be true.

7. The seventh hypothesis which states that IT Capability has a significant effect on Business Innovation can be proven to be true.

8. The eighth hypothesis which states that digital transformation has a significant effect on business innovation can be proven to be true.

\section{SUGGESTIONS}

Based on the conclusions above, suggestions can be given as follows: First, based on the fact that the CEO of Digital Leadership is not proven to be able to moderate the influence of technological excellence and IT alignment with business on digital transformation, it is recommended that UMKMs want to carry out digital transformation so set high standards in the field of technology understanding and technology-based business strategies for leaders to plan business, technology procurement and technology utilization that are relevant to the company's business objectives, so that there is no imbalance in the process of operationalization.

Secondly, the value of R2 obtained can be said to be quite small, which indicates that there are still many other variables that might influence digital transformation and innovation business, so further research can be suggested to add independent variables that can influence both.

\section{REFERENCES}

[1] Anonim. (2018, November). 3 Fakta Menarik Soal Koperasi dan UKM Tahun 2019. Diambil kembali dari Dinas Koperasi \& Usaha Kecil Provinsi Jawa Barat: http://diskumkm.jabarprov.go.id/index.php/article/3-fakta-menariksoal-koperasi-dan-ukm-tahun-2019

[2] Ganguly, A. (2015). Optimalization and Digital Transformation: Strategic Imperative for Creating a New Value Delivery Mechanism and A Sustainable Future In Organization. European Journal of Business and Innovation Research, 3(2), 1-13.

[3] Ghozali, I. (2014). Structural Equation Modeling, Metode Alternatif dengan Partial Least Square (PLS). Semarang: Badan Penerbit Universitas.

[4] Hecklau, F., Galeitzke, M., Flachs, S., \& Kohl, H. (2016). Holistic approach for human resource management in Industry 4.0. 6th CLF 6th CIRP Conference on Learning Factories, 6(1), 1-6.

[5] Kwon, E. H., \& Park, M. J. (2017). Critical Factors on Firm's Digital Transformation Capacity: Empirical Evidence from Korea. International Journal of Applied Engineering Research, 12(22), 12585-12596.

[6] Nwankpa, J. K., \& Roumani, Y. (2016). IT Capability and Digital Transformation: A Firm Performance Perspective. Thirty Seventh International Conference on Information Systems, 1-16.

[7] Prasetyo, H., \& Sutopo, W. (2018). Industri 4.0: Telaah Kasifikasi Aspek dan Arah Perkembangan Riset. UNDIP: Jurnal Teknik Industri, 13(1), 17-26.

[8] Rastislav, R., \& Silvia, L. (2015). Strategic Management of Business Performance Based on Innovations and Information Support in Specific Conditions of Slovakia. Journal of Competitiveness, 7(1), 321.

[9] Roeslani, R. P. (2018, Desember). Kadin Ungkap Tantangan UKM Masuki Era Revolusi Industri 4.0. Diambil kembali dari Viva.co.id: https://www.viva.co.id/berita/bisnis/1102111-kadin-ungkaptantangan-ukm-masuki-era-revolusi-industri-4-0

[10] Sarwono, J., \& Narimawati, U. (2004). Membuat Skripsi, Tesis dan Disertasi dengan Partial Least Square SEM (PLS-SEM). Yogyakarta: ANDI.

[11] Sow, M., \& Aborbie, S. (2018). Impact of Leadership on Digital Transformation. Business and Economic Research, 8(3), 139-148.

[12] Sugiyono. (2012). Metode Penelitian Kuantitatif dan Kualitatif. Bandung: CV. Alfabeta. 